Our Nature (2009) 7:187-192

\title{
Addition to the List of Brackish Water Zygnemaceae of Sundarbans and its Adjoining Areas, India Genus Spirogyra Link
}

\author{
N.M. Naskar ${ }^{*}$, K.R. Naskar ${ }^{1}$ and S. Talai ${ }^{2}$ \\ ${ }^{1}$ Central Inland Fisheries Research Institute (ICAR), Kolkata Centre, Salt Lake, Kolkata-700064, \\ West Bengal, India \\ ${ }^{2}$ Department of Botany, Hlarimohan Ghose College, Kolkata- 700024, India \\ *E-mail: nurmohammadnaskar@yahoo.com \\ Received: 11.01.2009, Accepted: 19.04.2009
}

\begin{abstract}
A total 12 species of Spirogyra Link was recorded from brackish water of Indian Sundarbans and its adjoining areas. Spirogyra dubia and Spirogyra ternata are found in the present study which was reported earlier. Spirogyra setiformis is uncommon to the present study which was also recorded earlier. This study represents 10 species of Spirogyra are being reported for the first time from this region.
\end{abstract}

Key words: Algae, brackish water, Spirogyra, Sundarbans, India

\section{Introduction}

Brackish water of Sundarbans has long and traditional background of bheri fisheries in North and South 24 Parganas Districts of West Bengal, India. The Sundarbans cover an area about $9000 \mathrm{~km}^{2}$ which is estimated about $34 \%$ in Indian Territory and $66 \%$ is in the Bangladesh. Sundarban is the largest continuous block of deltaic mangrove estuary in the world (Chaudhuri and Choudhuri, 1994). The average temperatures of Indian Sundarbans are $27^{\circ} \mathrm{C}$ during summer and $17-20^{\circ} \mathrm{C}$ during winter and average annual rainfall is $175-200 \mathrm{~cm}$. The population of Sundarbans is 40 lakhs and population density with 694 persons / $\mathrm{km}^{2}$.

Brackish water of Indian Sundarbans and its adjoining areas provide a unique habitat for algae and its enormous diversity and abundance have an impact on the faunal diversity of brackish water wetlands (Naskar, 2008).

The reports on brackish water algae from Indian Sundarbans are noticed in the works of Naskar and Santra (1985), Mandal and Naskar (1994), Sen et al. (1977), Sen and Naskar (2000), Sen (2003) and Naskar et al. (2006, 2007, 2008a, 2008b). The present study on algal biodiversity in brackish water of Sundarbans with the administrative blocks viz. Hingalganj, Sandeshkhali I and II, Haroa, Hasnabad and Minakhan and its adjoining areas with the blocks viz. Basirhat I and II, Baduria, Barasat II, Rajarhat and Deganga of North 24 Parganas, West Bengal, India reveals the Chlorophyceae second largest algal community as to compare with Cyanophyceae (largest community), Bacillariophyceae, Xanthophyceae, Chrysophyceae, Dinophyceae and Rhodophyceae. The Chlorophyceae 
N.M. Naskar, K.R. Naskar and S. Talai / Our Nature (2009) 7: 187-192

represents the orders Ulotrichales, Ulvales, Cladophorales, Oedogoniales, Zygnematales, Desmidiales and Chlorococcales. The 10 species of Spirogyra representing the family Zygnemaceae are not recorded earlier from brackish water of Sundarbans and its adjoining areas in India.

\section{Materials and Methods}

The study was carried out (2002-2005) in brackish water area of Sundarbans and its adjoining areas of North 24 Parganas district, West Bengal, India (Fig. 1). The location of the study sites cover an area about 34000.48 ha and lie at $22^{0} 26^{\prime}-23^{\circ} \mathrm{N}$ and $88^{0} 39^{\prime}-88^{0} 28^{\prime} \mathrm{E}$.

The salinity spectrum divides the study area as Station 1 (Sandeshkhali I and II), Station 2 (Hingalganj, Haroa, Hasnabad, Minakhan, Basirhat I and II, Baduria) and Station 3 (Barasat II, Rajarhat and Deganga).

Algal samples were collected during 1011 am covering the seasons summer, monsoon, post monsoon and winter by plankton net (mesh size $25 \mu \mathrm{m}$ ), scalpel and forceps and preserved in $4 \%$ formalin. The samples were deposited at the CIFRI (ICAR) laboratory in Kolkata Centre. The camera lucida drawings and some microphotographs were also taken from preserved and fresh materials for identifying the specimens. Identification of algae based on the keys of Biswas (1949) and Randhawa (1959). The water parameters viz. $\mathrm{p}^{\mathrm{H}}$, temperature and salinity were also studied following APHA (1975).

\section{Results and discussion \\ Taxonomic enumeration \\ Division Chlorophyta \\ Class Chlorophyceae \\ Order Zygnematales}

\section{Family Zygnemaceae \\ Genus Spirogyra Link}

1. Spirogyra maravillosa Transeu (Pl. 1, Fig. 1)

Randhawa, 1959, P. 388, Fig. 443.

Filaments green; vegetative cells $52-56 \mu \mathrm{m}$ broad, $124-140 \mu \mathrm{m}$ long with plane end walls; 2-3 chloroplasts making 2-5 turns in the cell.

Locality: Station-3 (Deganga), free floating, winter.

2. Spirogyra neglecta (Hassall) Kützing (Pl. 1, Fig. 2)

Biswas, 1949, P. 82, Pl. 6, Figs. 60a-b; Randhawa, 1959, P. 324, Fig. 308.

Filaments green; vegetative cells $52-65 \mu \mathrm{m}$ broad, $165-169 \mu \mathrm{m}$ long, cells long 2 times or more than broad, septa plane; 3 chloroplasts making $2 \frac{1}{2}$ turns.

Locality: Station-2 (Basirhat II), freefloating, winter.

3. Spirogyra angolensis Welwitsch (Pl. 1, Fig. 3)

Randhawa, 1959, P. 324, Fig. 324.

Filaments yellow-green; cells longer than broad, $52-61.75 \mu \mathrm{m}$ broad, $156-182 \mu \mathrm{m}$ long, plane end wall; 2 or 3 chloroplasts making 2 or 3 turns.

Locality: Station-3 (Barasat II), freefloating, monsoon.

4. Spirogyra hyalina Cleve (Pl. 1, Fig. 4) Randhawa, 1959, P. 318, Fig. 294.

Filaments yellow-green; vegetative cells $45.5-52 \mu \mathrm{m}$ broad, 94-130 $\mu \mathrm{m}$ long with plane end walls; chloroplasts 4 , making 3 turns.

Locality: Station-3 (Barasat II), freefloating, monsoon. 
N.M. Naskar, K.R. Naskar and S. Talai / Our Nature (2009) 7: 187-192

5. Spirogyra majuscula Kützing (Pl. 1, Fig. 5)

Randhawa, 1959, P. 344, Fig. 348.

Filaments yellow green; vegetative cells 52$58.5 \mu \mathrm{m}$ broad, $224-247 \mu \mathrm{m}$ long, much longer than broad, end walls plane; chloroplasts 4, reticulate appearance.

Locality: Station-3 (Barasat II), freefloating, monsoon.

6. Spirogyra irregularis Nägeli (Pl. 2, Fig. 6)

Randhawa, 1959, P. 316, Fig. 290.

Filaments greenish, slender; vegetative cells

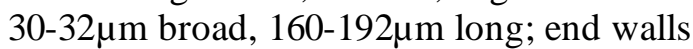
plane; chloroplast 2 in number making single turn.

Locality: Station- 2 (Hasnabad), freefloating, monsoon and post monsoon.

7. Spirogyra condensata (Vaucher) Kützing (Pl. 2, Fig. 7)

Randhawa, 1959, P. 291, Fig. 245.

Filaments yellow-green; vegetative cells 52$65 \mu \mathrm{m}$ broad, $71.5-104 \mu \mathrm{m}$ long, septa of the cells plane; chloroplast single forming 1 to $2 \frac{1}{2}$ spirals.

Locality: Station-3 (Barasat II), freefloating, winter.

8. Spirogyra juergensii Kützing (Pl. 2, Fig. 8)

Randhawa, 1959, P. 94, Fig. 250.

Filaments deep green; vegetative cells 25$44 \mu \mathrm{m}$ broad, $120-128 \mu \mathrm{m}$ long, up to 5 times long as broad, septa swollen; single chloroplast making more than two turns.

Locality: Station-2 (Hasnabad), freefloating, monsoon.

9. Spirogyra sahnii Randhawa (Pl. 2, Fig. 9)

Randhawa, 1959, P. 307, Fig. 274.
Vegetative cells $60-64 \mu \mathrm{m}$ broad, $68-76 \mu \mathrm{m}$ long, as long as broad, swollen and barrel shaped, septa plane; chloroplast single and arranged in an irregular fashion.

Locality: Station-2 (Basirhat II), freefloating, winter.

10. Spirogyra silvicola Britton (Pl. 2, Fig. 10)

Randhawa, 1959, P. 403, Fig. 478.

Vegetative cells longer than broad, 32$33 \mu \mathrm{m}$ broad, $84-104 \mu \mathrm{m}$ long; cells with single chloroplast making upto 3 turns in the cell.

Locality: Station-3 (Deganga), free-floating, monsoon.

The study area as a whole is an extraordinary in terms of algal species richness and diversity. Brackish waters are biologically more productive than fresh water or even sea water whether inshore or offshore (Sanjeevraj, 2003). The abundance and biodiversity of algae in the brackish water of Sundarbans and its adjoining areas influence the ecosystem function which in turn increases the fish production of the study area (Naskar, 2008). Spirogyra is the sign of polluted and turbulent water and indicator of high levels of organic pollution, high concentration of heavy metals, high levels of nutrients (Venkateswarlu and Reddy, 1997).

The genus Spirogyra is found during monsoon, post monsoon and winter only. Temparature and light have important role in regulating algal growth but the water temperature is not a significant factor for algal growth as it was always within the biokinetic range and never fall below $12^{\circ} \mathrm{C}$ (Knopp, 1960). But it definitely played an important role in regulating the seasonal spectrum of algae. Brackish water was 
N.M. Naskar, K.R. Naskar and S. Talai / Our Nature (2009) 7: 187-192
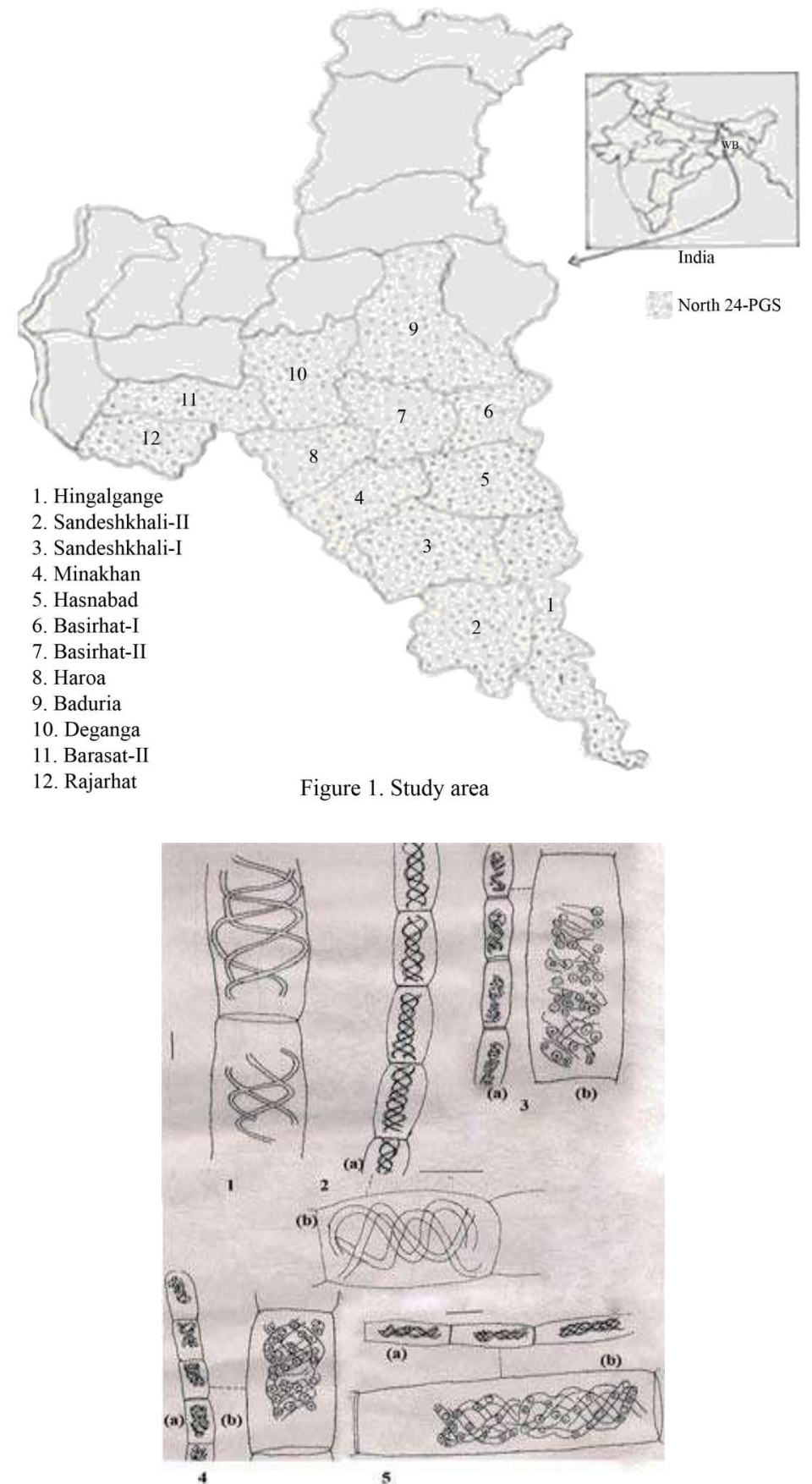

Plate 2: Figure 1. Spirogyra maravillosa Transeu, 2. Spirogyra neglecta (Hassall) Kütz., 3. Spirogyra angolensis Welwitsch, 4. Spirogyra hyalina Cl., 5. Spirogyra majuscula Kütz.. Scale bar: Figs 1, 2(b), 3(b), 4(b), $5(\mathrm{~b})=20 \mu \mathrm{m} ;$ Figs $2(\mathrm{a}), 3(\mathrm{a}), 4(\mathrm{a}), 5(\mathrm{a})=100 \mu \mathrm{m}$ 
N.M. Naskar, K.R. Naskar and S. Talai / Our Nature (2009) 7: 187-192

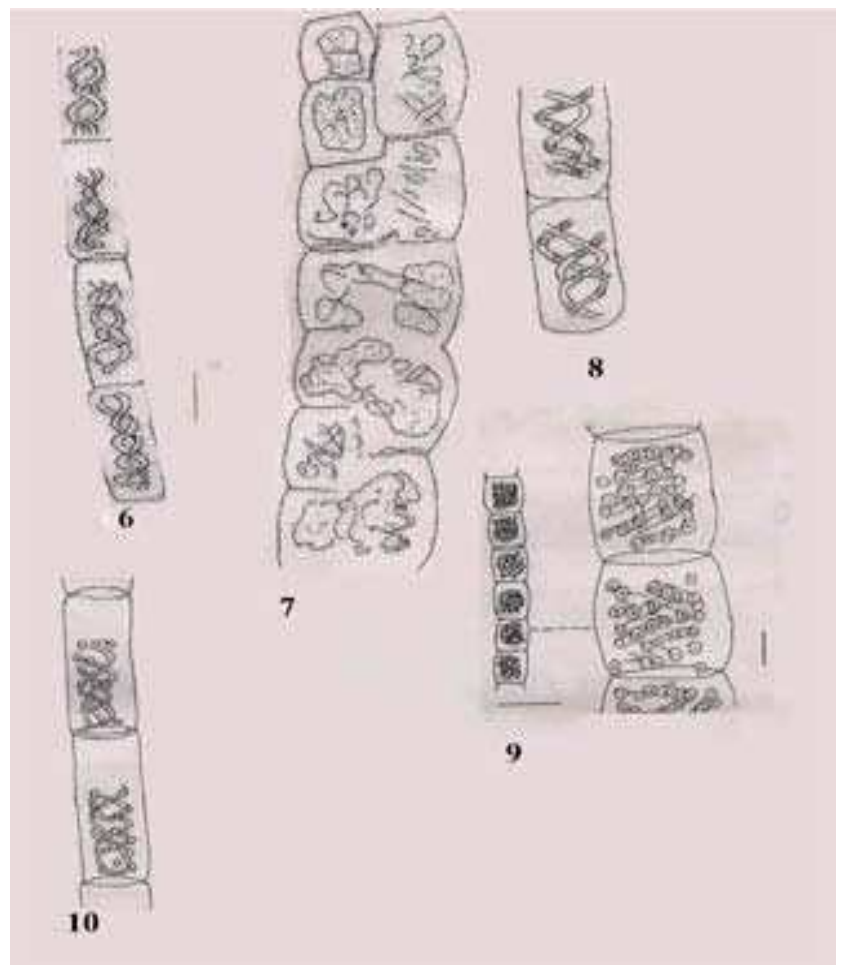

Plate 3: Figure 6. Spirogyra irregularis Näg., 7. Spirogyra condensata (Vaucher) Kütz., 8. Spirogyra juergensii

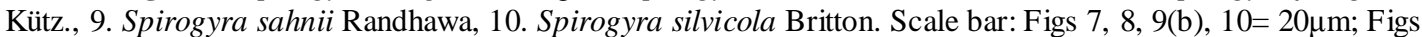
$6,9(a)=100 \mu \mathrm{m}$.

Table 1. Occurrence and distribution of Spirogyra spp. in brackish water of Sundarbans and its adjoining areas, India.

\begin{tabular}{lllll}
\hline Locality & $\begin{array}{l}\text { Average } \\
\text { salinity }\left(\mathrm{gl}^{-1}\right)\end{array}$ & $\begin{array}{l}\text { No. of } \\
\text { species }\end{array}$ & $\begin{array}{l}\text { Average } \\
\text { Temperature }\left({ }^{0} \mathrm{C}\right)\end{array}$ & $\begin{array}{l}\text { Average } \\
\mathrm{p}^{\mathrm{H}}\end{array}$ \\
\hline Station 1 (Sandeshkhali I and II) & 15.1 & Nil & 26.05 & 8 \\
Station 2 (Hingalganj, Haroa, Hasnabad, & 6.7 & 6 & 24.65 & 8.15 \\
Minakhan, Basirhat I and II, Baduria) & 5.9 & 6 & 26.95 & 8.25 \\
Station 3 (Barasat II, Rajarhat and Deganga) & 5.9 & 65 & \\
\hline
\end{tabular}

alkaline as the $\mathrm{p}^{\mathrm{H}}$ values are always above 7 (Table 1) supports high algal number than acid waters (Woodson, 1960).

The salinity values also played an important role affecting the distribution and growth of algae in the brackish water. The Station 1 with average salinity value $15.1 \mathrm{gl}^{-}$ 1 is not favourable for the growth of Spirogyra spp. which showed total absence from this zone (Table 1). The average salinity values with $5.9 \mathrm{gl}^{-1}$ of station 3 and $6.7 \mathrm{gl}^{-1}$ of station 2 (Table 1) appear to be favourable for the growth of Spirogyra spp. Hence, the certain salinity values favour the occurrence of this group of algae. So, the distribution and occurrence of Spirogyra spp. may be used for bio-monitoring study. 
N.M. Naskar, K.R. Naskar and S. Talai / Our Nature (2009) 7: 187-192

\section{Acknowledgements}

The authors are grateful to the Director of CIFRI (ICAR) for providing laboratory facilities and heartfelt thanks for Prof. Kashinath Bhattacharya, Botany Department, Visva-Bharati University for his gracious support.

\section{References}

APHA 1975. Standard methods for the examination of water and wastewater $\left(14^{\text {th }}\right.$ ed) American Public Health Association, Washington, D.C.

Biswas, K. 1949. Common fresh and brackish water algal flora of India and Burma, 15, Rec. Bot. Surv. India. $105 \mathrm{p}$.

Chaudhuri, A.B. and A. Choudhury 1994. Mangroves of the Sundarbans, India. IUCN, Glad, Switzerland. 245p.

Knopp, H. 1960. Untersuchungen Uberdas sauerst off-Production-potential Van Frussplankton. Schwerz. Z. Hydrol. 22: 152-166

Mandal, R.N. and K.R. Naskar 1994. Studies on the periphytic algae on the aerial roots of the mangroves of Sundarbans in West Bengal, In Environmental pollution and impact of Technology on life (Ed. M. Roy), Recent Researches in Ecology, Environment and Pollution. 9: 91-104.

Naskar, K.R. and S.C. Santra 1985. A note on Enteromorpha tubulosa in brackish water mixed sewage fed fisheries from the Sundarbans in West Bengal. J. Ind. Soc. Coast. Agric. Res. 5(2): 471472.

Naskar, N.M. 2008. Hydrobiological studies on the wetlands in the district 24 Parganas (North) with special reference to identification and impact assessment of the algae on brackish water fisheries, University of Calcutta, West Bengal, India. (Ph.D. Thesis)

Naskar, N.M., K.R. Naskar and C.R. Sen 2006. A systematic account of Chroococcales (Myxophyceae) from brackish water wetlands of North 24 Parganas District, West Bengal. Environ. Ecol. 24(3): 655-657.

Naskar, N.M., K.R. Naskar and C.R. Sen 2007.
Systematic account and ecology of Chlorococcales from Brackish water Bheries (wetlands) of North 24 Parganas District of West Bengal. Geobios 34: 17-20.

Naskar, N.M., K.R. Naskar and C.R. Sen 2008a. Brackish water Oscillatoriaceae from North 24 Parganas, West Bengal, India. Bangladesh J. Plant Taxon. 15(1): 31-38.

Naskar, N.M., K.R. Naskar and S. Talai 2008b. Occurrence of six species of Spirulina Turpin em Garden from the coastal wetlands of North 24 Parganas District, West Bengal, India. Seshaiyana 16(1): 4-5.

Naskar, N.M. and K.R. Naskar 2007. Diversity of Ulotrichales in estuarine wetlands of North 24 Parganas District, West Bengal. Indian Hydrobiol. 10(2): 249-255.

Randhawa, M.S. 1959. Zygnemaceae. Indian Council of Agricultural Research, New Delhi, 478p.

Sanjeevaraj, P.J. 2003. Strategies for conserving the macrofauna of Pulicat lake- A case study. In Natural Aquatic Ecosystems of India. Thematic Biodiversity Strategy and Action Plan, Zoological Survey of India, Chennai. pp. 228-238.

Sen, N., D. Sarkar, A.K. Sarkar and K.R. Naskar 1977. A note on the algal flora of Sundarbans. $J$. Intercad. 1(3): 177-182.

Sen, N. 2003. Taxonomy and Ecology of the Algal flora of Sundarbans Mangals in West Bengal (India) with special reference to estimation of their contribution to the primary productivity of the Estuarine Ecosystem. University of Calcutta, West Bengal, India. (Ph.D. Thesis)

Sen, N. and K.R. Naskar 2000. Colpomenia sinuosaA new report of brown algae from the Indian Sundarbans. J. Ind. Soc. Coast. Agric. Res. 18(2): 177-179.

Venketshwarlu, V. and P.M. Reddy 1997. Water quality monitoring in the rivers of Andhra Pradesh. In Workshop on "Water Pollution Assessment and Management", Indo-German Nachkontakt. Assoc., NGRI, Hyderabad.

Woodson, B.R. 1960. A study of the Chlorophyta of the James river basin, Virginia, II. Ecology. Virginia J. Sci. 2: 27-36. 